\title{
Determinants Influencing the Level of Corruption in Indonesia Local Governments
}

\author{
Muhammad Syauqi Qur'ani Putra Ariva, Ermawati \\ Universitas Pembangunan Nasional Veteran Jakarta, Indonesia \\ ermawati@upnvj.ac.id
}

\begin{abstract}
This study is based on the high levels of corruption occurring in Indonesia, indicated by the low level of the Corruption Perception Index (CPI). The majority of corruption cases occurring in Indonesia involves local governmental institutions. The high levels of corruption in local governments is related to government size, fiscal decentralization, and audit findings. The aim of this study is to determine the factors that cause the high levels of corruption in local governments. This study uses the agency theory as theoretical basis to formulate a framework of thought that connects government size, fiscal decentralization, audit findings, and corruption levels. The result of this study shows that the variables of government size, fiscal decentralization, audit findings, all have significant effects towards corruption levels. Fiscal decentralization and audit findings have a negative effect towards corruption level, while the government size variable has a positive effect on corruption levels. This study provides contribution to the practices of auditing, government execution, law enforcement, and corruption control initiatives in local governments in Indonesia.
\end{abstract}

Keywords: Government Size, Fiscal Decentralization, Audit Findings, Corruption Levels.

\section{Introduction}

Corruption is one of the issues in developing countries (Olken, 2007). The practice of corruption in government bodies causes the decrease of governmental performance in managing resources, decrease of national revenue from the tax sector, the distortion of public expenditure, and the decrease of public infrastructure quality. The final effect of the chain caused by the practice of corruption is revenue discrepancy, and poverty (Mauro, 1995). The Corruption Perception Index (CPI), released by the Transparency International (TI) organization is one of the instruments to measure the success of a country in handling and eradicating cases of corruption. The lower the rate of corruption cases in a country, the higher the CPI score obtained, and vice versa. Countries with a stable economic condition tend to have a higher CPI score compared to developing countries. This is due to the fact that the Gross Domestic Product (GDP) is an influencing factor in predicting corruption in a country (Bernaldez, 2014). Indonesia ranks 85 out of 180 countries, with a CPI score of 40 points (Transparancy International, 2019). This score represents a relatively high level of corruption cases in Indonesia. However, there have been improvements with regards to regulation, decentralization, and law enforcement supremacy that have been implemented since the institutional reformation at the end of the 1990s, which caused economic and political crisis in Indonesia. This event drove Indonesia to become more democratic, decentralized, and regulated (Henderson \& Kuncoro, 2011).

\section{Figure 1: Number of Corruption Cases Based on Institution}
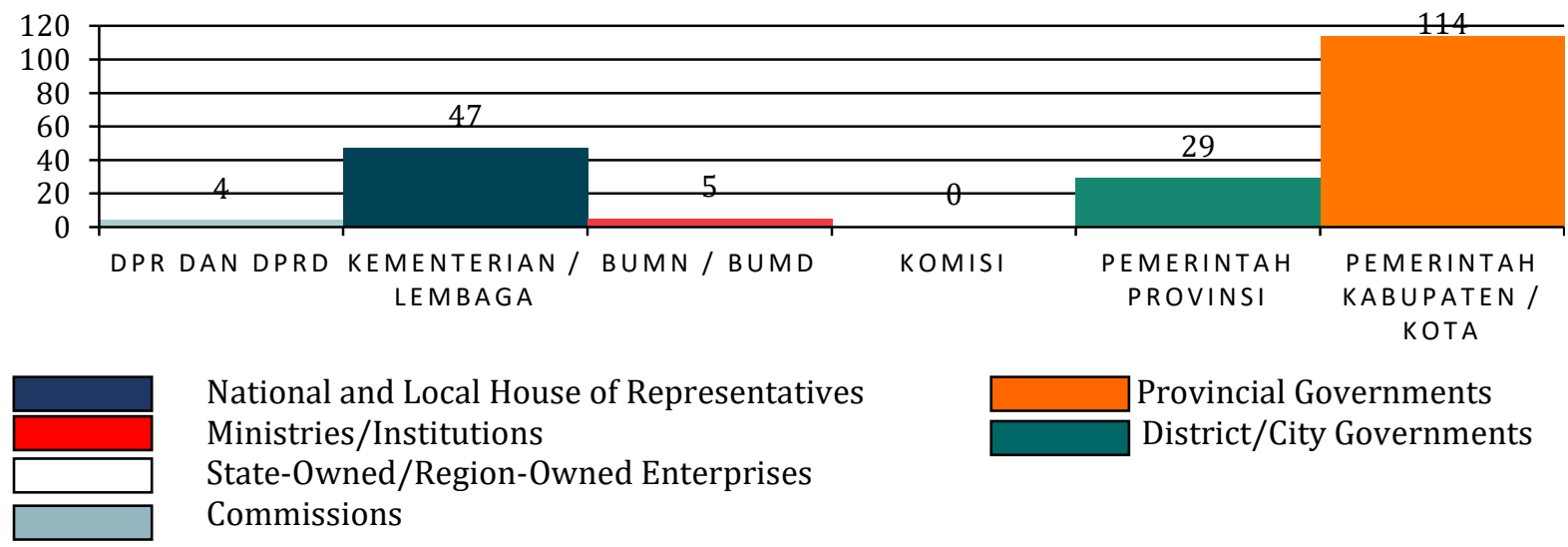

National and Local House of Representatives

Ministries/Institutions

Provincial Governments

State-Owned/Region-Owned Enterprises

District/City Governments

Commissions 
During 2018, a total of 199 cases of corruption spread across governmental institutions occurred. The Commission for Corruption Eradication categorizes this corruption case data based on governmental institutions, as shown in Figure 1. The data shows that the governmental institution with the highest prevalence of corruption cases are district/city local governments. Anan (2019) stated that decentralization is one of the causes of the high levels of corruption in local governments of Indonesia. Previous studies have also shown that fiscal decentralization has a significant effect towards corruption levels (Anan, 2019; Dong \& Torgler, 2013; Fisman \& Gatti, 2002). On the other hand, decentralization is one of the instruments to combat practices of corruption. Fiscal decentralization creates a more accountable and responsive government practice towards the condition of the region's people.(Changwony \& Paterson, 2019; Faguet, 2014; Shah, 2006). This statement is supported by the research findings of Aswar dan Surbakti (2013), which states that the implementation of fiscal decentralization in Indonesia helps in decreasing discrepancies between regions, since its mechanism aids local governments in managing resources according to the needs of the people in the region. Another study also found that fiscal decentralization can also increase the quality of the government in regards to corruption management, law supremacy, and government effectivity (Kyriacou \& Roca-Sagalés, 2011; Mello \& Barenstein, 2001). Suhardjanto, Syafruddin, Andini and Rahmatika (2018) state that the implementation of decentralization.

In Indonesia provides opportunity for the practice of corruption through the misuse of authority by people with power, in both small and large governments. A previous study showed that government size significantly affects corruption levels (Blackburn, Bose, \& Emranul Haque, 2006; Goel \& Nelson, 1998; Magtulis \& Poquiz, 2017). The size of the government can be viewed from the size of intervention done by the country through the budget (Magtulis \& Poquiz, 2017). However, the size of budget intervention can affect the high rates of corruption if not accompanied with strict monitoring. This is due to the fact that government officials often times benefit from the loophole of budget intervention through public expenditure, in order to practice corruption (Ko \& Zhi, 2013; Zhao \& Xu, 2015). Another previous study also shows that government size affects the level of corruption in a region (Goel \& Nelson, 1998; Liu \& Lin, 2012). The lack of monitoring and governance becomes the cause of the prevalence of corruption in the public sector (Olken, 2007). To prevent cases of corruption in local governments, there needs to be monitoring done by the central government towards local governments (Suhardjanto et al., 2018). The National Audit Board (BPK) is the institution that is responsible to conduct examinations to ensure that a governmental institution manages resources with proper accountability, based on the Constitution of the Republic of Indonesia, Law Number 15 Year 2006 on the National Audit Board. Examinations conducted by governmental audit institutions become the indicator of the transparency and accountability level of governmental institutions (Suhardjanto et al., 2018).

Auditing institutions guarantee the quality and availability of information provided by the government (Brusca, Manes Rossi, \& Aversano, 2018; Hameed, 2005). Furthermore, the examination mechanism implemented by the audit institution based on information accuracy and the prevention of financial misuse, enables the audit institution to detect fraud in the government (Brusca et al., 2018; Liu \& Lin, 2012; Olken, 2007). A proper audit process can decrease the level of corruption in the public sector (Gustavson \& Sundström, 2018). Ferraz and Finan (2011) state that, when audit institutions work independently and objectively, then deviations or violation cases reported to the audit institution can indicate the presence of corruption practices in the government. Frauds detected during the audit process are reported in the form of audit findings (Liu \& Lin, 2012; Suhardjanto et al., 2018). More audit findings show a low level of accountability, and potentially causes corruption (BPK, 2019). A previous study also found that audit findings has a significant effect towards corruption levels (Liu \& Lin, 2012; Suhardjanto et al., 2018). This study provides literary contribution by adding the variable of audit findings as an indicator of the weakness of internal control systems, and obedience towards regulations, according to the recommendation of the study conducted by Adedeji, Soyinka and Sunday (2018). The study recommended the use of obedience towards shared regulations, and internal control, to control corruption. Besides theoretical benefits, this study also provides several wide implications for the practice of auditing, government practices, law enforcement, and the initiative of corruption eradication in the local governments of Indonesia. 


\section{Literature Review and Hypothesis Development}

Agency Theory: The agency theory discusses the agency relationship and agency costs that occur in the relationship between the principal and the agent (Eisenhardt, 1989). The agency theory assumes that a person who prioritizes their own interest shows the conflict of interest between the principal and the agent (Jensen \& Meckling, 1976). Corruption can be defined as a behavior that does not follow the principal, done by the agent, by private sectors or public officials (Tanzi, 1994). In the public sector, cases of corruption occur due to the misuse of resources by parties from the government, for personal use. This can occur due to the difference in interest and motivation between two parties, as well as asymmetry of information (Eisenhardt, 1989). Blackburn et al. (2006) states that the delegation of authority in government transactions causes an agency problem that can cause corruption practices. The formation of audit institutions in the government is aimed to implement monitoring towards the performance of the agent, and works to mitigate agency problems that occur in the public sector (Hay \& Cordery, 2018; Aswar, 2019). A previous study also used the agency theory as the theoretical basis to form a conceptual framework, in a research related to sector public audit and corruption levels (Avis, Ferraz, \& Finan, 2018; Brusca et al., 2018; Ferraz \& Finan, 2011; Hay \& Cordery, 2018). Aside from this, the agency theory was also the framework basis of the relationship between government practices and levels of corruption (Blackburn et al., 2006; Magtulis \& Poquiz, 2017; Zhang, 2016). In previous literature, many studies have discussed the role of government size in affecting corruption levels.

Focusing on government size, Magtulis and Poquiz (2017) studied the relationship between government size and corruption levels in the Philippines using the auto regression vector. The result of this study did not find a causal relationship between the two research variables, since the perception of corruption can affect the other three control variables. The result of the study showed that a larger government size will increase the perception of the public on corruption. In another study, Ko and Zhi (2013) analyzes the relationship between fiscal decentralization and corruption levels in local governments in China with moderation from law enforcement. The analysis used data from 31 provinces in China from 1998 until 2008, and the investigation result supports the importance of strong law enforcement for fiscal decentralization in order to decrease the rate of corruption in local governments. Particularly, this study found that law enforcement can moderate the relationship between fiscal decentralization and levels of corruption. Suhardjanto et al. (2018) studies the relationship between audit opinion, audit findings, and audit result follow-up, with the corruption levels in local governments of Indonesia. The data analysis process used data from 34 provincial governments from 2011 until 2015. The result of the study showed that corruption occurs due to a weak monitoring system caused by the misuse of authority by government officials. The result of the study also found that lack of monitoring can cause disobedience towards laws, and thus cause corruption practices.

Hypothesis and Conceptual Framework: The hypothesis development in this study is based on factors suspected to have effects towards levels of corruption, and is thus formulated as follows:

The Effect of Government Size towards Corruption Level: In the context of the agency theory, the government size variable is described as the relationship between the central government and local government. The central government provides incentives to the local governments in the form of a budget that must be managed by the local government. This paradigm is formed due to the fact that the measurement of government size is done by measuring the size of intervention done by the country towards the budget of the government's budget (Magtulis \& Poquiz, 2017). This measurement causes larger-sized governments to increase the provision of public goods, and re-distribute revenue to push development (Goel \& Nelson, 1998; Zhao \& Xu, 2015). Blackburn et al. (2006) stated that the delegation of authority in government transactions causes an agency problem, which can result in corruption practices. A previous study also showed that the size of responsibility given by the central government affects the level of corruption in local governments (Goel \& Nelson, 1998; Lecuna, 2012; Liu \& Lin, 2012). This is due to the fact that government officials benefit from loopholes in the public expenditure policy to practice corruption (Ko \& Zhi, 2013). Based on theory and previous studies, the researcher formulates the following hypothesis:

H1: Government size affect corruption level.

The Effect of Fiscal Decentralization towards Corruption Level: Blackburn et al. (2006) stated that the delegation of authority by the central government to local governments causes an agency problem, which can 
result in corruption practice. This statement is supported by a previous study which states that decentralization is one of the factors behind the prevalence of corruption in local governments (Anan, 2019; Ko \& Zhi, 2013). However, Shah (2006) states that decentralization can strengthen public accountability by involving the people to monitor the performance of local governments and demand corrective actions, including demanding authorized parties to mitigate corruption and its causes. This accountability aids the government in its war against corruption practices (Brusca et al., 2018). This statement is also supported by the study conducted by Kyriacou and Roca-Sagalés (2011), which found that the concept of fiscal decentralization enables local governments to become more effective in controlling corruption and law enforcement. Another previous study also supports that fiscal decentralization can decrease the amount of corruption in a region (Dong \& Torgler, 2013; Fisman \& Gatti, 2002; Mello \& Barenstein, 2001; Shah, 2006). Based on theory and previous studies, the researcher formulates the following hypothesis:

H2: Fiscal decentralization affect corruption level.

The Effect of Audit Findings towards Corruption Level: The delegation of authority and responsibility by the central government to local governments can cause an agency problem, which can result in corruption practices (Blackburn et al., 2006). Corruption can be defined as an act of disobedience towards the principal, done by the agent (Tanzi, 1994). In the public sector, corruption practices often occur due to the issue of asymmetry of information and incentives that are explained in the agency theory (Elbahnasawy, 2014). The central government attempts to mitigate this asymmetry of information with the formation of an audit institution, tasked to monitor the financial performance of agents (Hay \& Cordery, 2018). All forms of deviations done by the local government during the operational process that is found by the audit institution is reported in the audit findings result (Liu \& Lin, 2012; Suhardjanto et al., 2018). Deviation findings are categorized into two types, which are: findings of weaknesses in the internal control system, and on disobediences towards laws. All forms of weaknesses of internal control systems and disobedience towards regulations will effect deviating actions which can result in corruption practices (Huefner, 2011). A previous study also found the positive correlation between audit findings and level of corruption (Liu \& Lin, 2012; Suhardjanto et al., 2018). This positive correlation indicates that a large number of audit findings found by the government audit institution has an effect in the prevalence of corruption. Based on theory and previous studies, the researcher formulates the following hypothesis:

H3: Audit findings affect corruption level.

Figure 2: Research Framework

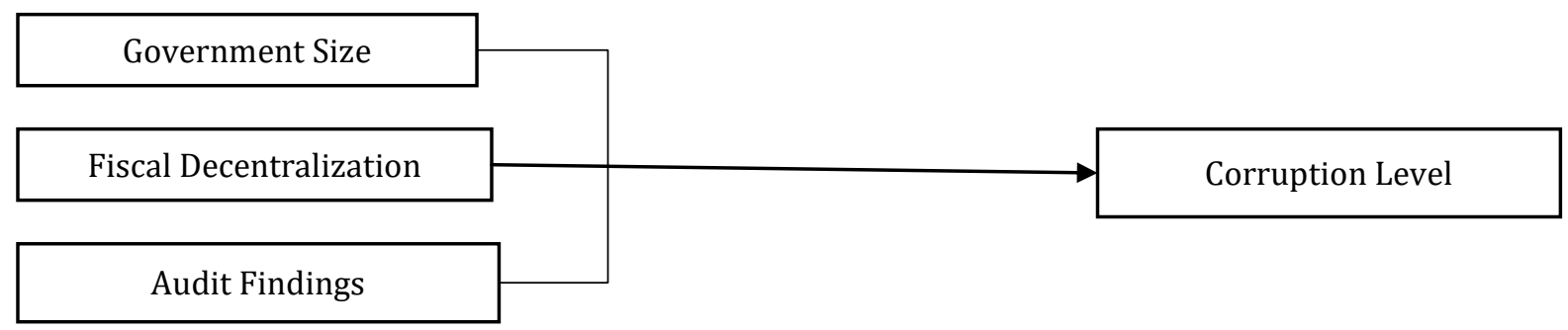

\section{Research Methodology}

The population of this study is the district/city governments in Indonesia, which consists of 416 district governments and 98 city governments. The district/city governments were selected based on the phenomenon of this study, which shows that corruption cases in Indonesia are most prevalent in district/city governments. Furthermore, district and city governments are the lowest level of government in the fiscal decentralization system in Indonesia. The researcher gathers samples based on criteria that the researcher set, from the total population of this study, using the purposive sampling technique. The criteria used in this sampling process is as follows:

a) District/city governments that have corruption cases with legal power, based on the verdict of the national court in 2018.

b) District/city governments that have data of audit result findings reports issued by the National Board of Audit of the Republic of Indonesia (BPK RI). 
c) District/city governments that have complete data for all the variables of this study for the 2018 fiscal year. Furthermore, the collection of data for this study was done through publications in the official website and electronic communication media of the related institution. The data gathered consists of Local Government Financial Reports (LKPD), Examination Result Report (LHP) of the BPK, Corruption Case Reports, Population Data, and RGDP Data. This study uses the causal research method. The causal method is used to identify the effects of government size, fiscal decentralization, and audit findings towards the corruption level in local governments of Indonesia. Each variable in this study has its own measurement, which are adopted from previous studies. The methods of variable measurement are shown in Table 1.

Table 1: Variable Measurement

\begin{tabular}{lll}
\hline Variable & Measurement & Source \\
\hline Corruption & $\begin{array}{l}\text { Corruption level is measured using a comparison ratio } \\
\text { between the number of corruption cases with legal power, } \\
\text { and the amount of population per 10.000. }\end{array}$ & \\
Government Size & $\begin{array}{l}\text { Comparison ratio of total local government expenditure to } \\
\text { the total of Regional Gross Domestic Product (RGDP) }\end{array}$ & $\begin{array}{l}\text { Magtulis and Poquiz } \\
\text { (2017) }\end{array}$ \\
$\begin{array}{l}\text { Fiscal } \\
\text { Decentralization }\end{array}$ & $\begin{array}{l}\text { Fiscal Decentralization is measured with the ratio of total } \\
\text { local government expenditure to the total of central }\end{array}$ & Paterson (2019) \\
gudit Findings & $\begin{array}{l}\text { government expenditure. } \\
\text { The amount of audit findings on weaknesses in the internal }\end{array}$ & Liu and Lin (2012) \\
& control system, and audit findings on disobediences towards & \\
\hline
\end{tabular}

\section{Results and Discussion}

The population of this study is 514 district and city governments in Indonesia. The selection of samples used the purposive sampling technique. The end samples of this study are shown in Table 2.

Table 2: End Samples of Research

\begin{tabular}{ll}
\hline Criteria & Total \\
\hline Population & 514 \\
District/city governments that do not have cases of corruption with legal power based on the & $(368)$ \\
verdict of the national court in 2018 & \\
District/city governments that do not have data on the number of audit findings issued by the & $(3)$ \\
BPK RI & \\
District/city governments that do not have complete data for all the variables of research for the & $(0)$ \\
No18 fiscal year & 143 \\
Number of samples before outliers & $(35)$ \\
Samples with outliers & 108 \\
End samples & \\
\hline
\end{tabular}

Upon conducting filtering towards the population data of the study as shown in Table 2, the researcher conducted an outlier process to obtain consistent research data. Outlier was done using case-wise diagnostics using SPSS software, which considers the standard deviation as its reference. Standard deviation is the measure of data deviation level from the research data center (Sekaran \& Bougie, 2016, hlm. 284). Data deviation can be viewed by comparing the standard deviation score to the average score. If the standard deviation variable exceeds the score of the average variable, then the data has a low deviation rate, and vice versa (Cooper \& Schindler, 2013, hlm. 401). Aside from that, outlier is also conducted manually to dispose of extreme data in the research data. The number of samples with outlier are 29 district governments and 6 city governments. The end samples obtained after conducting outlier is 90 district governments and 18 city governments. Furthermore, the researched conducted a series of analysis, which consists of: descriptive statistics, and hypothesis testing, using the multiple linear regression method. The process of data analysis 
was done using the Statistical Package for Social Sciences (SPSS) application. The descriptive statistics of the research data is shown in Table 3.

Table 3: Descriptive Statistics

\begin{tabular}{llllll}
\hline & N & Minimum & Maximum & Mean & Std. Deviation \\
\hline Corruption Level & 108 & 0,00171 & 0,21726 & 0,042325 & 0,035212 \\
Government Size & 108 & 0,01501 & 0,53073 & 0,118876 & 0,092151 \\
Fiscal Decentralization & 108 & 0,00024 & 0,00294 & 0,00064 & 0,000449 \\
Audit Findings & 108 & 5 & 24 & 12,74 & 3,705 \\
Valid N (listwise) & 108 & & & & \\
\hline
\end{tabular}

Based on Table 3, there are 108 end samples. Corruption level has a maximum score of 0.21726 , minimum score is 0.00171 . The standard deviation of corruption level is less than the average score of corruption level, which indicates a low level of deviation in the research data. The maximum score of government size is 0.53073. Meanwhile, the minimum score of government size is 0.01501 . The standard deviation of government size is less than the average score of government size, which indicates a low level of deviation in the research data. Fiscal decentralization has a maximum score of 0.00294 . Meanwhile, the minimum score of fiscal decentralization is 0.00024 . The standard deviation of fiscal decentralization is less than the average score of fiscal decentralization, which indicates a low level of deviation in the research data. Furthermore, the maximum score of audit findings is 24. Meanwhile, the minimum score of audit findings is 5 audit findings. The standard deviation of audit findings is less than the average score of audit findings, which indicates a low level of deviation in the research data. The classical assumption test, consisting of the normality test, heteroscedasticity test, and multicollinearity test, shows that all classical assumption tests have been fulfilled and the double linear regression test can be performed. The hypothesis testing used the multiple linear regression test.

Table 4: Result of Multiple Linear Regression

\begin{tabular}{llll}
\hline Model & Coefficient & T & Sig. \\
\hline (Constant) & 0,031 & 3,679 & 0,000 \\
Government Size (GS) & 0,288 & 13,052 & 0,000 \\
Fiscal Decentralization (FD) & $-15,058$ & $-3,314$ & 0,001 \\
Audit Findings (AF) & $-0,001$ & $-1,988$ & 0,049 \\
R-Square & 0.713 & & \\
\hline
\end{tabular}

The test results in Table 4 show that the value of R-Square obtained is 0.713 . This score is the representation of the collective effects of Government Size, Fiscal Decentralization, and Audit Findings towards the variable of Corruption Level, which is $71.3 \%$ out of $100 \%$. Meanwhile, the remainder of $28.7 \%$ is affected by other variables outside of this study. The regression coefficient value of government size is 0.288 and positive. This proves that government size has a positive effect towards corruption level, of 0.288 . Government size also has a calculated $t$ value of 13.052 , or larger than the $t$ table value of 1.983 , with a significance rate of less than 0.05 . Therefore, it can be concluded that the first hypothesis of this study is accepted. The result of this study states the existence of a positive and significant effect in the relationship between government size, and corruption level. The size of the government can be viewed from the size of budget intervention done by the central government towards the local government (Magtulis \& Poquiz, 2017). This enables larger-sized governments to provide more public needs and revenue distribution well. However, this intervention is often misused by government officials through budget discretion, to conduct corruption practices (Zhao \& Xu, 2015). The lack of monitoring towards the budget intervention of the central government becomes one of the issues.

Which can result into deviations done by government officials, even though the central government at present has formed monitoring institutions and law enforcement institutions in order to prevent cases of corruption? The result of this study is in line with a previous study which stated that government size 
determines the level of corruption (Goel \& Nelson, 1998; Lecuna, 2012; Liu \& Lin, 2012). However, a different result is shown in the study conducted by Magtulis and Poquiz (2017), which showed that a large government size does not always correspond with high levels of corruption in the Philippines. The regression coefficient value of fiscal decentralization is 15.058 and negative. This proves that fiscal decentralization has a negative effect towards corruption level, of -15.058. Fiscal decentralization also has a calculated t value of $-3,314$, or larger than the $t$ table value of 1.983 , with a significance rate of less than 0.05 . Therefore, it can be concluded that the second hypothesis of this study is accepted. The result of this study found that there is a negative effect in relationship between fiscal decentralization and corruption level. The result of this study opposes the statement of Blackburn et al. (2006), which stated that delegation of authority in government transactions from the central government to local governments causes an agency problem that can cause corruption practices.

On the other hand Di Shah (2006) states that decentralization can strengthen public accountability by involving the people to monitor the performance of local governments and demand corrective actions, including demanding authorized parties to mitigate corruption and its causes. This accountability aids the government in its war against corruption practices. This statement is also supported by the study conducted by Kyriacou and Roca-Sagalés (2011), decentralization can also increase the effectivity of the government in regards to corruption management, and law enforcement. fiscal decentralization can decrease the amount of corruption in a region (Dong \& Torgler, 2013; Fisman \& Gatti, 2002; Mello \& Barenstein, 2001; Shah, 2006). However, this result is not in line with the findings of Anan (2019), which found that decentralization is one of the factors behind the prevalence of corruption in local governments. The regression coefficient value of audit findings is 0.001 and negative. This proves that audit findings have a negative effect towards corruption level, of -0.001 . Audit findings also has a calculated $t$ value of -1.988 , or larger than the $t$ table value of 1.983 , with a significance rate of less than 0.05 . Therefore, it can be concluded that the third hypothesis of this study is accepted. The result of this study found that there is a negative effect between audit findings and corruption level. The result of this study opposes a previous study that found a positive effect.

Between audit findings and corruption level (Liu \& Lin, 2012; Suhardjanto et al., 2018). Aside from that, the findings of this study is also not in line with the concept of agency theory, which states that audit findings are a form of disobedience and deviation done by the agency towards the principal, which can cause losses or misuse of resources by the local government (Huefner, 2011). This result difference with previous research and inconsistency with the agency theory is due to the fact that the corruption data used by the researcher is corruption data that already had legal power in 2018. Meanwhile, not all cases of corruption with legal power in 2018 occurred in that same year. This can be cause by cases having only been exposed in 2018, or the lengthy legal process taken during the course of the case. Meanwhile, audit findings used were actual findings in 2018. However, this difference can be explained by the result findings of a study conducted by Avis et al. (2018), which found that local governments that have been audited by audit institutions can decrease the level of corruption in the future by as much as $8 \%$. The number of audit findings does not always correspond with the high level of corruption in the same period. However, audit findings can become a signal of a weak internal control system, and disobedience towards local government laws. If not responded seriously, this can become a loophole for corruption practitioners. Therefore, audit findings can also become a preventive step to prevent the involvement of corruption practitioners earlier on, and prevent cases of corruption from occurring in the future.

\section{Conclusion and Recommendations}

Corruption is still a significant issue in Indonesia. This is reflected by the CPI score obtained by Indonesia in 2018, which is 40 points, despite the fact that the government has published steps to decrease corruption in Indonesia, after the political and economic crisis in 1998. This study aims to identify the relationship between government size, fiscal decentralization, audit findings, law enforcement, and corruption level in local governments in Indonesia. The result of this study found that government size, fiscal decentralization, and audit findings, have a significant effect towards the corruption level in Indonesia. This study provides several wide implications for the practices of audit, government execution, law enforcement, and the initiative of corruption control in the local governments in Indonesia. Keeping in mind that corruption is still an issue in Indonesia; the researcher recommends all local governments in Indonesia to practice government 
transparently and accountably. The implementation of these principles is aimed to be able to decrease the corruption level in regions. Local governments are also expected to be able to involve the role of the people to aid in monitoring the course of a government that is free from corruption practices. Monitoring must also be done by law enforcers, especially those tasked to handle corruption cases.

Law enforcers are expected to be able to monitor and act firmly on corruption practitioners. Therefore, the researcher recommends to increase the availability of national court for criminal corruption (PN TIPIKOR) in Indonesia. This recommendation is made based on the Constitution of the Republic of Indonesia, Law Number 46 Year 2009 on the Corruption Court, which states that the PN TIPIKOR exists in every district/city. At present, there are only a total of 33 PN TIPIKOR, which is less than the total number of districts/cities in Indonesia, which is 514. There are several limitations experienced by the researcher during the process of research. This study is limited to the scope of corruption cases that occur after the reformation. The lack of available data caused the researcher to experience difficulty in obtaining data related to cases of corruption before the reformation. Aside from that, the scope of this study is only limited to findings from government external audit. The next researcher is expected to add the element of government internal audit, and law enforcement. Based on findings from the study conducted by Ko and Zhi (2013), the law enforcement variable moderates the effect of fiscal decentralization towards corruption level in China.

\section{References}

Adedeji, D. B., Soyinka, K. A. \& Sunday, O. M. (2018). Corruption Control in the Public Sector and the Nigerian Accountant. International Journal of Academic Research in Accounting, Finance and Management Sciences, 8(1), 91-103.

Anan, E. (2019). Effect of Fiscal Desentralization and Region-wide Corruption Level in Indonesia. In Proceedings of the International Conference of Democratisation in Southeast Asia (ICDeSA 2019), 367, 246-251.

Aswar, K. \& Surbakti, L. P. (2013). Pengaruh Desentralisasi Fiskal Terhadap Pendapatan Asli Daerah Dan Belanja Publik Kabupaten/Kota di Indonesia. In Proceeding PESAT (Psikologi, Ekonomi, Sastra, Arsitektur, dan Teknik Sipil), 5, 161-169.

Aswar, K. (2019). Financial performance of local governments in Indonesia. European Journal of Business and Management Review, 4(6), 1-6

Avis, E., Ferraz, C. \& Finan, F. (2018). Do Government Audits Reduce Corruption? Estimating the Impacts of Exposing Corrupt Politicians. Journal of Political Economy, 126(5), 1912-1964.

Badan Pemeriksa Keuangan. (2019). Ikhtisar Hasil Pemeriksaan Semester 1 Tahun 2019.

Bernaldez, P. B. (2014). Determinants of Political Corruption: A Conceptual Framework. International Journal on Graft and Corruption, 1(1), 53-79.

Blackburn, K., Bose, N. \& Emranul Haque, M. (2006). The incidence and persistence of corruption in economic development. Journal of Economic Dynamics and Control, 30(12), 2447-2467.

Brusca, I., Manes Rossi, F. \& Aversano, N. (2018). Accountability and Transparency to Fight against Corruption: An International Comparative Analysis. Journal of Comparative Policy Analysis: Research and Practice, 20(5), 486-504.

Changwony, F. K. \& Paterson, A. S. (2019). Accounting practice, fiscal decentralization and corruption. The British Accounting Review, 51(5), 1-21.

Cooper, D. \& Schindler, P. (2013). Business Research Methods: 12th Edition. McGraw-Hill Higher Education.

Dong, B. \& Torgler, B. (2013). Causes of corruption: Evidence from China. China Economic Review, 26(1), 152169.

Eisenhardt, K. M. (1989). Agency Theory: An Assessment and Review. Academy of Management Review, 14(1), 57-74.

Elbahnasawy, N. G. (2014). E-Government, Internet Adoption, and Corruption: An Empirical Investigation. World Development, 57, 114-126.

Faguet, J. P. (2014). Decentralization and Governance. World Development, 53, 2-13.

Ferraz, C. \& Finan, F. (2011). Electoral Accountability and Corruption: Evidence from the Audits of Local Governments. American Economic Review, 101(4), 1274-1311.

Fisman, R. \& Gatti, R. (2002). Decentralization and corruption: evidence across countries. Journal of Public Economics, 83(3), 325-345. 
Goel, R. K. \& Nelson, M. A. (1998). Corruption and government size: A disaggregated analysis. Public Choice, 97(1-2), 107-120.

Gustavson, M. \& Sundström, A. (2018). Organizing the Audit Society: Does Good Auditing Generate Less Public Sector Corruption? Administration \& Society, 50(10), 1508-1532.

Hameed, F. (2005). Fiscal Transparency and Economic Outcomes (WP/05/255). IMF Working Papers.

Hay, D. \& Cordery, C. (2018). The value of public sector audit: Literature and history. Journal of Accounting Literature, 40(November 2016), 1-15.

Henderson, J. V. \& Kuncoro, A. (2011). Corruption and local democratization in Indonesia: The role of Islamic parties. Journal of Development Economics, 94(2), 164-180.

Huefner, R. J. (2011). Fraud risks in local government: An analysis of audit findings. Journal of Forensic and Investigate Accounting, 3(3), 111-125.

Jensen, M. C. \& Meckling, W. H. (1976). Theory of the firm: Managerial behavior, agency costs and ownership structure. Journal of Financial Economics, 3(4), 305-360.

Ko, K. \& Zhi, H. (2013). Fiscal Decentralization: guilty of aggravating corruption in China? Journal of Contemporary China, 22(79), 35-55.

Kyriacou, A. P. \& Roca-Sagalés, O. (2011). Fiscal and Political Decentralization and Government Quality. Environment and Planning C: Government and Policy, 29(2), 204-223.

Lecuna, A. (2012). Corruption and Size Decentralization. Journal of Applied Economics, 15(1), 139-168.

Liu, J. \& Lin, B. (2012). Government auditing and corruption control: Evidence from China's provincial panel data. China Journal of Accounting Research, 5(2), 163-186.

Magtulis, P. P. \& Poquiz, J. L. (2017). Big Government, Big Corruption? Examining the Relationship between Government Size and Public Corruption in the Philippines. International Journal of Public Administration, 40(11), 954-967.

Mauro, P. (1995). Corruption and Growth. The Quarterly Journal of Economics, 110(3), 681-712.

Mello, L. \& Barenstein, M. (2001). Fiscal Decentralization and Governance: A Cross-Country Analysis (WP/01/71).

Olken, B. A. (2007). Monitoring Corruption: Evidence from a Field Experiment in Indonesia. Journal of Political Economy, 115(2), 200-249.

Pemerintah Republik Indonesia. (2006). Undang-Undang Republik Indonesia Nomor 15 Tahun 2006 Tentang Badan Pemeriksa Keuangan (2006). Indonesia.

Pemerintah Republik Indonesia. (2009). Undang - Undang Republik Indonesia Nomor 46 Tahun 2009 Republik Indonesia Tentang Pengadilan Tindak Pidana Korupsi (2009). Indonesia.

Sekaran, U. \& Bougie, R. (2016). Research Methods For Business: A Skill Building Approach. Wiley.

Shah, A. (2006). Corruption and decentralized public governance (WPS3824). Retrieved from The World Bank:

Suhardjanto, D., Syarifuddin, M., Andini, R. P. \& Rahmatika, M. W. (2018). Accountability and Corruption Level of Provincial Government in Indonesia. Review of Integrative Business \& Economics Research, 7(3), 281-296.

Tanzi, V. (1994). Corruption, governmental activities, and markets (WP/94/99). Retrieved from International Monetary Fund:

Transparancy International. (2019). Corruption Perseption Index 2019. Retrieved 2 February 2020, from https://www.transparency.org/cpi2019?/news/feature/cpi-2019

Zhang, S. (2016). Fiscal Decentralization, Budgetary Transparency, and Local Government Size in China. Emerging Markets Finance and Trade, 52(7), 1679-1697.

Zhao, X. \& Xu, H. D. (2015). E-Government and Corruption: A Longitudinal Analysis of Countries. International Journal of Public Administration, 38(6), 410-421. 